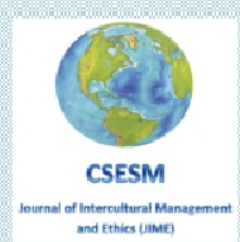

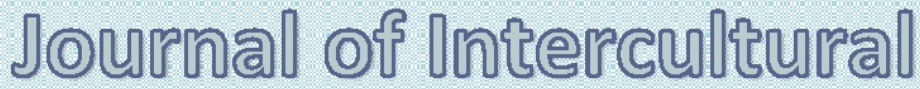

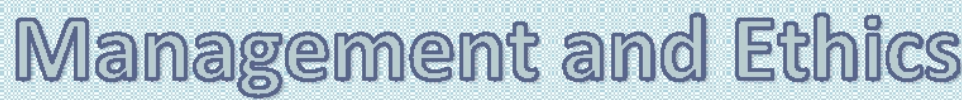

\author{
IOME
}

ISSN 2601 - 5749, ISSN-L 2601 - 5749

\section{published by zy \\ Center for Socio-Economic Studies and Multiculturalism \\ lasi, Romania \\ Waw csesmorg}




\section{Special Editor}

\section{Professor Beatrice Gabriela Ioan, PhD, MD}

Grigore T.Popa University of Medicine and Pharmacy of Iasi, Romania

E-mail: ioanbml@yahoo.com

\section{TABLE OF CONTENT}

Editorial ....

Beatrice Gabriela Ioan

Ethical Approaches on the Mandatory Vaccination in the Pandemic Context (Romania Case)

Andreea-Iulia Someșan, Ion Copoeru

Early Approaches in Management of Sars-Cov-2 Infection 19

Isabela-Ioana Loghin, Adriana-Florina Bahnă, Oana-Manuela Secrieru, Irina-Margareta

Nistor, Irina-Cristina Nicolau, Liviu Jany Prisăcariu, Florin Roșu, Victor Daniel Dorobăţ,

Cristin-Ioan Loghin, Carmen-Mihaela Dorobăț

Giving Birth during the Pandemic. How The Decision to Transform Certain Hospitals In Dedicated Covid-19 Medical Units Impacted Women on Psychological Level

Alexandra Ștefania Nadane

Evangelicalism in Uganda: Implications for Public Health and Bioethics

Sana Loue, Francis Bajunirwe

The Contribution of Ethics to the Development of the Healthcare System

Cornelia Margareta Găşpărel

Iatrogenesis Induced by Risk Reduction in Health Care

Mircea Gelu Buta

Ethical Contributions in Preserving the Dignity of the Terminal Patient

Elena Toader, Andreea Decusara, Mirela Piscuc, Tudor Winsinger

Ethical Aspects of the Institutionalization Process of Children from Outbreaks of

Tuberculosis

Rodica Gramma, Elena Cernăuțeanu, Adriana Paladi

Profession, Vocation, Mission or Work. The Ancient Physician and the Contemporary

Physician-Parallel Lives

Orsolya Horber, K.Zilahi 


\title{
EVANGELICALISM IN UGANDA: IMPLICATIONS FOR PUBLIC HEALTH AND BIOETHICS
}

\author{
Sana Loue ${ }^{1, *}$, Francis Bajunirwe ${ }^{2}$ \\ ${ }^{1}$ Case Western Reserve University School of Medicine, Cleveland, Ohio USA \\ ${ }^{2}$ Mbarara University of Science and Technology, Mbarara, Uganda \\ *corresponding author, E-mail: Sana.Loue@case.edu
}

\begin{abstract}
Considered attention is needed to the interplay between evangelical and charismatic religions and legislation in Uganda and their implications for public health, bioethics, and medical education. This manuscript examines the growth of the evangelical and charismatic movements in Uganda during the past several decades, concurrent trends in the formulation and implementation of law and public policy, and implications for the prevention and treatment of sexually transmitted infections, family violence, physician-patient communication, and medical and health education. The article concludes with suggested strategies to address the adverse consequences stemming from the interjection of religious perspectives into the domains of public health, clinical care, and health education.
\end{abstract}

Key words: Bioethics, evangelicalism, public health, Uganda

\section{Introduction}

This article begins with a brief review of evangelicalism and fundamentalism in Uganda. The discussion then focuses on an examination of the interplay between evangelicalism and fundamentalism and several recent legislative enactments and their implications in the broader contexts of gender-related violence, public health, clinical care, and ethics, aspects of the legislation that have been largely ignored in the international discourse. The article concludes with suggested strategies to address the apparent interjection of religious perspectives into the domains of public health, clinical care, and health education: the continuing education of health care professionals, health educators, and clergy and revisions to select Ugandan legislation.

\section{Evangelicalism and Fundamentalism in Uganda}

Uganda's continuing efforts to implement anti-gay legislation, including the imposition of the death penalty for same-sex sexual behavior, have been widely denounced as violations of human rights, and the population's increasing vitriol and discrimination against homosexuals have often been attributed to the influence of American evangelical and charismatic religious leaders (Boutchie, 2019; Kaoma, 2014; Kisitsu, 2018; Müller, 2011; Oliver, 2013; van der Laan \& van der Wal, 2014). In view of both the growth and growing influence of Uganda's own evangelical and fundamentalist denominations, this attribution of responsibility is misplaced.

Uganda's 2014 census recorded a significant increase in the proportion of the population that self-identified as Pentecostal/Born Again/Evangelical from 4.7 percent in 2002 to 11.1 percent in 2014, accounting for a total of slightly more than 3.79 million persons (Uganda Bureau of Statistics, 2002, 2014). Evangelicals are also present in Anglicanism, such as in the Church of Uganda (Zurlo, 2015). Although there was a decrease in the proportion of self-identified Anglicans, from 36.7 percent of the population in 2002 to 32 
percent in 2014, the number of persons remains substantial, at almost 11 million (McKinnon, 2020; Uganda Bureau of Statistics, 2002, 2014).

Although a rise in evangelicalism has occurred across sub-Saharan Africa (Anderson, 2007; Jenkins, 2002), it has been suggested that the increased voice of evangelicalism and fundamentalist faiths and the concomitant growth of their political influence in Uganda are attributable to the intervention of U.S.-based fundamentalist religious networks in local Uganda affairs (Boutchie, 2019; Hofer, 2003; Kaoma, 2014; Kisitsu, 2018; Oliver, 2013). Interactions between Uganda fundamentalists and their U.S. counterparts have often been at the forefront of both Ugandan local and international news; however, the emphasis on the responsibility of U.S.-based actors for their influence and their political positions is misplaced.

Evangelicalism in Uganda stretches back at least as far as 1877, when the Anglican Church Missionary Society began working in what was then the Buganda Kingdom (Bekele, 2015; Ssemugoma, 2021; Ward, 2015). The term "evangelical" is used here to refer to the network of Protestant revival movements that arose during the eighteenth and early nineteenth centuries in Great Britain and its colonies, including Uganda (Noll, 2004; Wolffe, 2015). Evangelicalism is characterized by a turning from self and sin to God and Jesus Christ (conversion); reference to the Bible as the decisive authority on all matters pertaining to faith and religious practice; participation in activities that disseminate the message of salvation in Christ; and recognition of Christ's death on the cross as the substitution for punishment for human sins and spiritual life for those who stand in Christ (Bebbington, 1989).

Some, but not most, evangelicals are fundamentalists, although these terms are often used synonymously. Fundamentalism is a term originally used to refer to conservative evangelicals in the United States who opposed the movement towards liberalization among some Christian denominations and adhered to more traditional views of the Bible's infallibility, Christ's virgin birth, and Christ's return at the end of the world (Marsden, 1980).

Pentecostalism refers to evangelicalism that emphasizes the role of the Holy Spirit, exorcism, and a direct experience with God (Asamoah-Gyadu, 2005; Ihejirika, 2006). The Pentecostal Assemblies of God was founded in Uganda in 1935 (Musana, 1991; Onyait, 2011), the Eim Church in 1962, the Full Gospel Church in 1962, and the Deliverance Church in 1967 (Musana, 1991). Churches such as the Anglican Church of Uganda share some characteristics with Pentecostalism, such as an emphasis on faith healing and speaking in tongues (Jenga, 2017).

It has been suggested that those who initially joined the Anglican Church lacked true commitment, failed to adhere to the faith's precepts, and were, in essence, engaged in the nominal practice of Christianity (Bruner, 2011; Ndyabahika, 1993; Ward, 1989). The Uganda Revival Movement, known as the Balokole ("the redeemed" or "the saved people") was part of the East African Revival (Ndyabahika, 1993) that sought to address the existence of widespread corruption and lack of morality (Ssemugoma, 2021). The Revival Movement is variously recounted as having begun in 1928, 1929, or 1930 (Ndyabahika, 1993; Ssemugoma, 2021; Zurlo, 2015).

Both the Balokole and non-Balokole currently exist within the Anglican Church of Uganda (Ndyabahika, 1993), but the term Balokole is now used to refer as well to all members of the Pentecostal movements and its churches in Uganda (Jenga, 2017; Ward, 1989). The Balokole has been credited with adding new members and vitality to the churches (Ndyabahika, 1993; Ward, 2001), an increased emphasis on missionary activities, "social purity and sobriety," the disappearance of "filthy and indelicate languages," the restoration of "pure speeches, and prayers and praises in lieu of "swearing and blasphemy" (Ndyabahika, 1993, p. 30; see also Byabazaire, 1978). Balokole gained even greater credence following 
President Museveni's declaration in the late 1990s that Balokole were more trustworthy than members of other faith communities (Ssemugoma, 2021).

The Pentecostal Assemblies of God established a church building in Uganda in or about 1960, following the grant of a permit to the Glad Tidings Missionary Society by thengovernor of Uganda, Sir Charles Hartwell (Onyait, 2011; Ssemugoma, 2021). The first Pentecostal revival in Uganda was held in February 1961. During this revival, the Kabaka offered his lake for people's baptism; 365 people were baptized (Ssemugoma, 2021). Although the Pentecostal church was banned by then-president Idi Amin in 1974 (Onyait, 2011), it continued to exist and, since the independence of Uganda from Great Britain in 1962, has experienced a continuous increase in membership (Bekele, 2015). The late 1980s and early 1990s have been described as "years of great revival" (Ssemugoma, 2021, n.p.). The identification of the First Lady, Janet Museveni, with Pentecostalism lent additional credibility and impetus to membership, as did the ministry of Apostle Deo Balabyekubo, which claimed to have brought about the cure of AIDS for more than 100 people through healing crusades during 1994 and 1995.

\section{Evangelicalism's Impact on Ugandan Society}

Uganda's three major faith communities-Islam, Catholicism, and Anglicanism-have enjoyed radio and television air time since the mid- 1950s and mid-1960s, respectively (Jenga, 2017). Private individuals and faith-based organizations have been able to purchase broadcast time since 1994, providing religious broadcasting in addition to the alreadyexisting broadcast time for the three faiths and the ecumenical programs of the Anglican, Catholic, and Orthodox churches.

Kampala is home to the largest concentration of both Pentecostal churches and pastors' broadcast media houses in the country. As of 2017, there were 20 Christian-affiliated radio and television stations in Kampala alone, 80 percent of which were affiliated with Pentecostal groups (Jenga, 2017). As one scholar has noted,

The strong Pentecostal presence in Uganda's media gives Pentecostals great influence not only in religious matters, but also the socio-political affairs of the country. The broadcast media has given Pentecostals visibility and a voice they did not have in the past and, in this development, one notices media intersecting with religion, but even more so with politics (Jenga, 2017, p. 63).

Indeed, several scholars have suggested that Pentecostals may soon dominate the sociocultural and political domains in Africa as a result of their increasing religious power (Tomaselli, 1995; Tomaselli and Shepperson, 1997). As an example, political candidates have been known to seek the endorsement of Pentecostal pastors, particularly near the time of elections (Central Intelligence Agency, 2015).

These broadcasts have, to a degree, replaced the use of crusades, which were experiencing decreases in attendance. The broadcasts frequently focus on messages relating to prosperity, social advancement, family life, and one's relationship with God, using Biblical texts as the foundation for these messages. The broadcasts also address listeners' beliefs about the larger world, providing advice on breaking curses and evil spells, protection from witchcraft, and promoting healing and prosperity. The broadcasts have been credited with the growth of pastors' congregations, the enlargement of pastors' public profiles, and the financial thriving of Kampala's broadcast industry (Jenga, 2017).

The Anglican Church considers itself, together with the Catholic Church, to be the guardian of public morality (Ward, 2015). Sermons from the pulpit of the (Anglican) Church of Uganda often focus on sin and immorality, including the vices of drink, womanizing, and smoking (Ward, 2015). Nevertheless, the Pentecostal churches have made salvation from sin "their trademark approach" in their ministry (Onyait, 2011). 
Although Uganda's Constitution provides in Article VII, "Uganda shall not adopt a State religion," religion plays a major role in Uganda's political, legal, and policy framework. Personal beliefs have been translated into government policy through the actions of various political figures. James Nsaba Buturo, an Anglican mulokole, became Uganda's Minister of Ethics and Integrity in 2006. In this capacity, he vociferously condemned homosexuality and sought to combat "corruption, homosexuality, pornography, and witchcraft" (Ward, 2015). He was replaced in 2012 by Simon Lukodo, a former Catholic priest, who continues Buturo's campaign against homosexuality.

Uganda has prohibited same-sex sexual relations since 1956, characterizing the behavior as "against the order of nature'; violation was punishable with life in prison (Penal Code Act, 1956). In 2007, Uganda's Minister of Ethics and Integrity formed the Interfaith Rainbow Coalition Against Homosexuality, which was responsible for organizing actions against homosexuality, including prayer gatherings, petitions, fasting campaigns, protest rallies, and street marches (Krieger, 2007; Pownall, 2007). Pastor Martin Ssempa, the spokesperson for the coalition, asserted, "Homosexuality breaks the laws of God, the laws of nature, and the laws of Uganda ... We are asking the government to be strong and uphold the laws of our country banning this repugnant practice" (Pownall, 2007).

The 2009 AntiHomosexuality Bill was introduced by David Bahati, a practicing Anglican (Ward, 2015). The bill, initially tabled, later signed into law in 2014 AntiHomosexuality Bill, 2014), and then found to be unconstitutional for lack of a quorum by Uganda's Constitutional Court (Oloka Onyango and Ors v. Attorney General, 2014) sought to "protect the cherished culture of the people of Uganda, legal, religious and traditional family values of the people of Uganda" against values of sexual promiscuity and to protect children from "sexual abuse and deviation" attributable to "cultural change" (AntiHomosexuality Bill, 2019). The passage of the 2009 bill was lauded by Stanley Ntagali, the Archbishop of the Anglican Church of Uganda (Aruho, 2014).

The impact of the churches' denunciation of homosexuality and of the bill on individuals who identify or are perceived to be gay has been well documented (Associated Press, 2014; van Klinken \& Zebracki, 2016; Wiener-Bronner, 2014) and will not be repeated in detail here. It is sufficient to note that the churches' rhetoric has provoked negative attitudes, leading to a fear of violence and police brutality and resulting secrecy within the nonheterosexual communities (Kaoma, 2014; Oliver, 2013); the murder of at least one gay activist (Boyd, 2015); and the denial of social services to individuals who self-identify or are perceived to be gay (Oliver, 2013).

Uganda's Anti-Pornography Act (Parliament of Uganda, 2014a) serves as yet another example of the impact of evangelicalism on larger aspects of Ugandan society. The Act was initially drafted in 2005 by Nsaba Buturo, the same Minister of Integrity and Ethics who denounced homosexuality (Tamale, 2016). President Museveni signed the bill into law in February 2014, following a series of revisions (Athumani, 2014). The law is intended to define pornography, protect children from predatory sexual behaviors, and establish a Pornography Control Committee (Dahir, 2017). Pornography is defined as:

any representation through publication, exhibition, cinematography, indecent show, information technology or by whatever means, of a person engaged in real or stimulated [sic] explicit sexual activities or any representation of the sexual parts of a person for primarily sexual excitement (AntiPornography Act, 2014, Part I, sec. 2).

Like the AntiHomosexuality Act, the Anti-Pornography Act has received the support of religious-political figures and appears to have provoked violence against would-be transgressors. Father Lukodo, noted above for his continuation of Buturo's campaign against homosexuality, asserted, 
Anything related to indecent dressing, exposing certain parts of the anatomy of a person, I call it pornographic and therefore condemn it ... when you go indecently on the streets of Kampala, you'll become ... a cinema ... Say what you want to say, but we're coming out with a law that people should go back to their decent way of covering their bodies ... (NTV Uganda, 2013).

Since the implementation of the law, vigilante groups have publicly undressed alleged female violators (Anon., 2014c; Yolisigira, 2014), police have ordered women to return to their homes and dress appropriately, and women who wore miniskirts have been sentenced to jail terms (Anon., 2014a).

These events prompted women to initiate public protests (Fallon, 2014); the Minister of Information and National Guidance to declare that the law did not prohibit miniskirts (Wandera, 2014); Father Lokodo to retract his earlier statement characterizing miniskirts as one of Uganda's vices (Anon., 2013; Salvo, 2014); the Ministers of Ethics and Integrity, of Information, and of Gender, Labour, and Social Development to deny that the law imposed a dress code for women; and the Prime Minister and Attorney General to promise to recall and review the law (Namutebi \& Kashaka, 2014; Sekyewa, 2014). To the best of this authors' knowledge, the law has not been recalled, but the women's protests were suppressed by the police under the authority of the Public Order and Management Act (Anon., 2014b; OlokaOnyango, 2014).

\section{Implications for Public Health, Clinical Care, and Health Education}

Uganda is widely credited for its proactive actions to decrease HIV transmission. Initially believed to have been caused by witchcraft seeking punishment of those who were guilty of a crime and those who had committed the sins of fornication or adultery, these beliefs about HIV/AIDS soon gave way to an understanding of the immensity of the health issue confronting the nation (Waliggo, 2004). In response to this health threat, Uganda instituted what has become known as the ABC campaign - abstinence, being faithful, and condom use (Müller, 2011; Murphy, Greene, Mihailovic, and Olupot-Olupot, 2006). To support its prevention and treatment efforts, the country established HIV peer education programs in its clinics, encouraged HIV testing, and collaborated with numerous international organizations, funders, and externally-funded research endeavors (Bruner, 2017). These successes may now be in jeopardy as the result of evangelical influence on legislation and societal perspectives (Perkins, 2008; Sadgrove, 2007; Setswe, 2007).

Although a number of churches have joined forces in an effort to reduce HIV transmission (Kagimu, Guwatudde, Rwabukwali, Kaye, Walakira, and Ainomugisha, 2011), others have acted in ways clearly detrimental to public health. As noted above, Apostle Deo Balabyekubo claimed to have brought about the cure of AIDS for more than 100 people through healing crusades during 1994 and 1995. Bishop Bataringaya Okumu, an evangelical Christian minister in Gulu District, blocked his adherents from obtaining medical care, promising that he could heal them through prayer. At least one HIV-infected individual died after ceasing his medication usage in response to Okumu's entreaties (United States Department of State, 2019). Several Pentecostal pastors and church officials have been accused of both encouraging romantic relationships between individuals knowing that at least one of them was HIV-infected and misappropriating individuals' property in exchange for promises of healing from HIV (Anon., 2009b; Lloyd, 2008). Others have urged their congregants to rely only on spiritual healing and forego antiretroviral treatment (Anon., 2008; Namige, 2019). Although research findings are somewhat inconsistent across studies, a number of studies indicate that some individuals have terminated their use of antiretroviral medication for their HIV in response to the teachings and prophecies of their religious leaders and testimonies from their peers claiming to have been cured of HIV through prayer 
(Tumwine, Neema, \& Wagner, 2012; Wanyama et al., 2007). Additionally, the abandonment of Uganda's pragmatic ABC prevention approach in favor of a more moralistic approach that emphasized abstinence until marriage and being faithful drew strong support from Uganda's evangelical communities (Parikh, 2015). This refashioned approach lacked a scientific evidence base and appears to have led to both an increase in the incidence and prevalence of HIV and a low level of condom supplies (Bass, 2005; Das, 2005; Ssegoba, 2004; Wakabi, 2008).

Evangelical leaders have also been implicated in disseminating misinformation about COVID-19 (Kirby, Taru, \& Chimbidzakai, 2020). It was recently reported that a Ugandan hospital that had received 5000 doses of vaccine had been able to inoculate only 400 persons because of the hesitancy of the evangelical population (Dias \& Graham, 2021). A study of attitudes among pregnant women in Uganda towards vaccination found an unwillingness of some women to receive vaccinations for preventable disease because it was prohibited by Pentecostal churches (Kajungu, Muhoozi, Stark, Weibel, \& Sturkenboom, 2020).

The effectiveness of public health prevention efforts and medical treatment efforts necessarily rest, both at the individual and the community levels, on the ability of health educators and care providers to engage in confidential discussions with individuals in an atmosphere of trust and candor (Brown, Bussell, Dutta, Davis, Strong, \& Mathew, 2016; Hébert, Hoffnaster, Glass, \& Singer, 1991; Rowe \& Moodley, 2013). Uganda's criminalization of sexual behavior between consenting adults and the vociferous religious rhetoric compromise the establishment of a safe environment for such communications.

Consider, for example, a patient who presents to a physician with symptoms indicative of depression and anxiety. The physician could merely prescribe medication to address the symptoms without inquiring as to the underlying circumstances that may have triggered the symptoms, an approach that is analogous to placing a bandage over an untreated wound. But what if these symptoms flow from the patient's questioning of his or her sexual orientation or fear that his/her sexual orientation will be discovered or the guilt that the individual is experiencing because of their sexual orientation? As evidenced by documented past events, the patient could suffer serious consequences if his or her sexual identity were to become known publicly. In 2009, several Kampala-based Pentecostal preachers held a press conference during which a teacher named George Oundo claimed to have been kidnapped by an NGO and transported to Nairobi, where he was bribed to recruit children to homosexuality as part of a larger endeavor to promote homosexuality in Ugandan schools (Anon., 2009a). A journalist with an independent press who merely covered issues relating to Uganda's gay community was subjected to questions about her own sexual orientation and was the focus of religious efforts to have her deported or punished with death (Krieger, 2007; Roubos, 2016). Indeed, at least one physician, Dr. Paul Semugoma, has publicly noted the dangers associated with homophobia, observing, "[H]omophobia keeps gays from seeking health services, which hurts everyone" (Roubos, 2016).

Uganda's current penal law not only prohibits sexual relations between individuals of the same sex, but also penalizes anyone who "does or omits to do any act for the purpose of enabling or aiding another person to commit the offense" or who "aids or abets another person in committing the offense" (Penal Code of Uganda Chapter 120, as amended, 2014). Such individuals may face prosecution as a principal offender to inciting the commission of an offense. One must query whether a health care provider or HIV educator could potentially face such criminal charges in response to their efforts to counsel nonheterosexals about safer sex practices; might this be interpreted by a zealous prosecutor as aiding and abetting the commission of an offense? Consider a possible scenario in which a patient, confronted with a physician's assurance of the normality of the patient's desires, experiences intensified feelings of guilt and vulnerability, denies his sexual orientation and, in an effort to protect 
him- or herself, publicly denigrates the physician, thereby bringing the encounter to public attention.

The religious rhetoric denouncing homosexuality and the provisions of Uganda's Penal Code chapter 120 have troublesome implications not only for Uganda's public health, but also for the education of public health personnel, health care providers, and bioethicists. The possibility of being questioned about one's own sexual orientation and threatened with violence, as experienced by the journalist noted above, may deter educators from broaching issues relating to sexual orientation, despite the importance of sexual orientation as a dimension of human sexuality. Bioethicists who wish to address the concept of vulnerability, a foundational concept in research ethics (DuBois, 2006; Kipnis, 2001; Levine, Fadden, Grady, Eckenwiler, \& Sugarman, 2004; Rogers, Mackenzie, \& Dodds, 2012), may be reluctant to do so with reference to sexual orientation or behavior for fear of the potential political and legal consequences. And students, just beginning to form their professional identities, may unconsciously integrate the negative attitudes voiced by their religious leaders and inject their unconscious biases into their interactions with their patients, potentially leading to a lesser quality of care and poorer health outcomes (Blair, Steiner, \& Havranek, 2011; FitzGerald \& Hurst, 2017; Marcelin, Siraj, Victor, Kotadia, \& Maldonado, 2019).

Uganda's Code of Professional Ethics, promulgated by the Uganda Medical and Dental Practitioners Council, is intended to be used as a guide "to promote and maintain the highest standards of ethical behaviour by practitioners in Uganda" (Uganda Medical and Dental Practitioners Council, 2014, preamble). The guide prohibits practitioners from violating the human rights of a patient or his or her family or caregiver and explicitly prohibits discriminations on the basis of "gender, race, disability, HIV status or any other indication of vulnerability" (Uganda Medical and Dental Practitioners Council, 2014, Part II). Notably, there is no explicit prohibition against discrimination on the basis of sexual orientation. Accordingly, a physician who believes that homosexuality constitutes a sin and it is his task to help redeem the patient could argue that such behaviour falls outside of the Code's prohibitions. The patient could then face private and/or public denunciation by the physician, leading to a future reluctance to seek medical care and possible repercussions from family members and/or the larger community. Alternatively, the physician could refuse to provide the patient with needed medical care and attention, premising this refusal on their religious beliefs and the absence of an explicit prohibition against such discrimination in the governing ethical code. Either scenario raises significant issues related to the foundational bioethical principles of respect for persons, beneficence, nonmaleficence, and justice.

And, this scenario is not improbable in view of the current widespread rhetoric and, as studies have found, the erosion of "professional values and ethical practices" within Uganda's health care system, including a lack of confidentiality, "abuse of patients" (Matsiko, 2010), and frequent harassment of patients by staff in health facilities (Uganda Law Reform Commission, 2017). Researchers conducting a study of stakeholder perceptions of patient-centered primary care reported that many patients are afraid to ask questions of their providers (Waweru, Sarkar, Ssengoba, Gruénais, Broerse, \& Criel, 2019). Yet another study found that more than one-half of 570 university students with a same-sex sexual orientation reported unmet health care needs, which was associated with poor mental health (Larsson, Ross, Tumwine, and Agardh, 2016). Almost one-third reported unmet sexual health needs, exposing them to an increased risk of poor mental health, frequent episodic drinking, and sexual coercion. It was unknown from the data collected whether individuals had refrained from seeking health care due to previous maltreatment by health care providers, which has been found to be the case in other sub-Saharan countries (Fay et al., 2011; Niang et al., 2003; Rispel et al., 2011; Sharma et al., 2008; Smith, 2015). 
The religious rhetoric underlying the Anti-Pornography Act may well be contributing to violence against women in Uganda, which is increasingly recognized as a "critical social and public health issue" (Ogland, Xu, Bartkowski, \& Ogland, 2014, p. 869; see also Black et al., 2019). Fifty-four percent of all women in Uganda have experienced intimate partner violence (IPV) (Karamagi, Tumwine, Tylleskar, \& Heggenhougen, 2006). The Uganda Demographic and Health Survey conducted in 2016 (Uganda Bureau of Statistics and ICF, 2018) found that more than 56 percent of all married women had ever experienced IPV and 40 percent of married women reported experiencing IPV during the 12 months preceding the survey (Gubi Nansubuga, \& Wandera, 2020), a rate that appears to be one of the highest in the world (Devries et al., 2010). Women with disabilities are at even greater risk than their non-disabled counterparts to experience IPV (Valentine, Akobirshoev, \& Mitra, 2019). Researchers conducting a prospective study with 455 women aged 18 years and older who were enrolled in the Uganda AIDS Rural Treatment Outcomes Cohort Study from 2005 to 2015 reported finding that 29 percent of the women reported ever having experienced IPV at baseline and almost 8 percent were currently experiencing IPV at baseline (Young et al., 2018).

Intimate partner violence is associated with various adverse health risks and outcomes. Research has found that IPV is a key driver of HIV incidence in Uganda (Uganda AIDS Commission, 2015), increasing women's risk of contracting HIV, often because their partners are engaged in higher HIV risk behaviors (Kouyoumdjian et al., 2013). Women who are experiencing IPV may choose to ignore HIV, fearing that a positive HIV test will trigger additional IPV against them (Institute of Medicine and National Research Council, 2015). Married women may be especially vulnerable; they may be unable to negotiate the use of a condom with their husband even when the husband has been involved in extramarital sexual relations because it may be perceived as mistrust and indicative of the wife's promiscuity (Gusman, 2009). IPV has also been found to be associated with miscarriages, unwanted pregnancies, premature labor, infant mortality, increased risk of sexually transmitted infections, low birthweight babies, and depression (Valentine, Akobirshoev, \& Mitra, 2019).

Although many factors apart from religion have been found to be associated with intimate partner violence in Uganda, including the male partner's use of alcohol, his controlling behaviors, the duration of the marital relationship, the number of children, the number of co-wives, the partners' levels of education and economic resources, and having witnessed parental violence (Amegbor and Pascoe, 2019; Black et al., 2019; Gubi, Nansubuga, \& Wandera, 2020), evangelicalism has also been tentatively implicated as a contributing factor. Being of Pentecostal faith may place women in Uganda at greater odds of experiencing physical and emotional partner violence over the course of their lifetimes, compared with their Protestant and Muslim counterparts (Ogland, Xu, Bartkowski, \& Ogland, 2014). An ethnographic study of several Pentecostal churches and HIV conducted in Kampala observed that church teachings

[charged] young men, not women ... to lead the country, and, as in the biblical tale [of Joseph], women are represented as morally weaker than men ... During weekly teachings given in separate gender groups, young women are taught that men are better suited for such work and that the role of a woman is mainly that of a mother and a wife (Gusman, 2009, p. 76).

A recent thesis by Isabirye (2020) that studied the development of the Pentecostal Deliverance Church in Busoga found that although the majority of congregants were women, there were no female pastors, a result that suggests and reinforces the precept that women should be deferential/subservient to men. This view appears to have infiltrated the health care arena as well. A report from a recent study of stakeholders' perceptions of patient-centered 
primary care noted that husbands are frequently the arbiters of decisions relating to their wives' medical care (Waweru et al., 2019).

\section{Considerations for a Way Forward}

We do not mean to suggest by this analysis that individuals who self-identify as members of fundamentalist or evangelical faith communities represent a monolithic perspective or that Uganda is alone in experiencing problematic effects of evangelicalism on its public health efforts. The United States, as an example, is confronting objections to the COVID-19 vaccine from its evangelical communities that are rooted in a distrust of science and scientists and a belief in the healing power of faith. (Dias \& Graham, 2021; Reeve, Guff, Waldrop, \& Brunswick, 2021). Ultimately a balance must be struck between respect for religion and people's right to worship as they choose and the need to protect the public health. That balance is necessarily dependent upon the particular context and the harms and benefits that may flow from a specified course of action.

Uganda has taken a number of steps that may lead to the establishment of a new balance, with greater importance placed on necessary public health efforts. Ugandan law requires that all churches register if they are working in conjunction with a charitable project. The government has closed nearly 12,000 churches and faith-based NGOs that have failed to fulfill the registration requirement (Semakula, 2019). As of 2003, the majority of the country's 2,000 accredited HIV/AIDS projects were affiliated with evangelical churches (Hofer, 2003). Uganda has proposed imposing a requirement of theological training for religious clergy, in an effort to protect congregants from "misleaders" (Agiresaasi, 2019).

While these efforts are noteworthy, they likely are inadequate to reverse the detrimental effects of past clergy pronouncements that have discouraged individuals from seeking or continuing appropriate care and that have led to violence against others. What is additionally called for are discussions that focus on the interplay, congruencies, and tensions that exist between theological precepts and scientific and medical advancements and the extent to which individuals may concurrently hold faith in both.

It is unknown whether the reported abuse and harassment of patients by health care providers is associated with providers' personal religious beliefs, fear or confusion about existing laws, or other factors. However, these findings from studies covering varying periods of time and employing different methodologies strongly suggest the need for continuing professional education that not only focuses on the substance of the ethical principles underlying the provision of care, but also addresses how such principles are to be enacted in the course of clinical care. The conscientious enactment by providers of these principles would lead to a diminution in incidences of patient abuse and harassment, more careful safeguarding of patient information, the provision of care to all patients regardless of their personal characteristics, and an effort to consider more fully women's situations and give voice to their health concerns and needs.

Uganda once had one of the best, if not the best, health care and public health infrastructure on the African continent (Macrae, Zwi, \& Gilson, 1996). It has fallen far from those heights, due to epidemics, wars, internal conflicts, and questionable reforms (Chattu \& Yaya, 2020; Dodge, 1990). Intimate links exist between Uganda's government and the evangelical and fundamentalist churches (Sadgrove, 2007); it is possible that some of these reforms may have been occasioned by political figures with personal religious agendas and religious persons seeking political influence. Considered attention to and efforts to reverse the adverse public health and ethical consequences of the more recent infusion of personal religious beliefs into policy and law will contribute to the improvement of Ugandans' health. 


\section{Acknowledgements}

We thank Dr. Timothy Scarnacchia of Kent State University's Department of History, Kent, Ohio, USA, for his review and comment on earlier versions of the paper. This research was supported in part by the Fogarty International Center, R25 TW01507. The opinions stated herein are those of the authors and do not represent or reflect those of the funding agency or its personnel.

\section{References}

Agiresaasi, A. (2019). Uganda's proposed church training law to protect congregants from 'misleaders,' officials say. Global Press Journal, May 2. https://globalpressjournal.com/africa/uganda/ugandas-proposed-church-training-lawprotect-congregants-misleaders-officials-say/. Accessed 06 April 2021.

Amegbor, P.M., \& Pascoe, L. (2019). Variations in emotional, sexual, and physical intimate partner violence among women in Uganda: A multilevel analysis. Journal of Interpersonal Violence, 1-31. https://doi.org/10.1177/ 0886260519839429.

Anderson, A. (2007). Spreading fires: The missionary nature of early Pentecostalism. Marknoll, NY: Orbis Books.

Anon. (2009a). Homosexual admits recruiting students. New Vision. http://www.newvision.co.ug/new_vision/news/1247426/homosexual-admitsrecruiting-students.

Anon. (2008). Spiritual healing threatening adherence to antiretrovirals in Uganda, official says. KHN, October 2. https://khn.org/morning-breakout/dr00054779/. Accessed 05 April 2021.

Anon. (2009b). Ugandan pastors accused of weakening the fight against HIV/AIDS. VOA, October 27. https://www.voanews.com/archive/ugandan-pastors-accused-weakeningfight-against-hiv-aids. Accessed 05 April 2021.

Anon. (2014a). Mob undresses 10 people over indecent exposure. Uganda News Releases, February 25. https://www.ugandanewsreleases.com/mob-undresses-10-people-overindecent-exposure/. Accessed 10 April 2021.

Anon. (2013). Uganda bill criminalises miniskirts. Mail \& Guardian, April 8. https://mg.co.za/article/2013-04-08-uganda-proposes-ban-on-miniskirts-in-moveagainst-womens-rights/. Accessed 10 April 2021.

Anon. (2014b). Uganda miniskirt ban: Police stop protest march. BBC News, February 26. https://www.bbc.com/news/world-africa-26351087. Accessed 10 April 2021.

Anon. (2014c). Women get three-hour jail term for wearing miniskirts. Uganda News Releases, March 7. https://www.ugandanewsreleases.com/women-get-three-hour-jailterm-for-wearing-miniskirts/. Accessed 10 April 2021.

Anti-Pornography Act, 2014, Parliament of Uganda (2014). https://www.ugcert.ug/files/downloads/The-Anti-pornography-act-2014.pdf. Accessed 10 April 2021.

Aruho, P. (2014). Homosexuality threat to mankind, says Archbishop. Daily Monitor, January 13, at 13 .

Asamoah-Gyadu, J.K. (2005). African charismatics: Current developments within independent indigenous Pentecostalism in Ghana. London: Brill.

Associated Press. (2014). Ugandan tabloid prints list of 'top 200 homosexuals.' The Guardian, February 25. https://www.theguardian.com/world/2014/feb/25/ ugandantabloid-prints-list-top-200-homosexuals. Access 03 April 2021.

Athumani, H. (2014). Museveni signs anti-pornography bill into law. Uganda Radio Network, February 14. https://ugandaradionetwork.net/story/museveni-signs-antipornography-bill-into-law. Accessed 24 April 2021.

Bass, E. (2005). Fighting to close the condom gap in Uganda. Lancet, 365(9465), 1127-1128. 
Bebbington, D.W. (1989). Evangelicalism in modern Britain: A history from 1730s to the 1980s. London: Unwin Hyman.

Bekele, G. (2015). Evangelicals in Eastern Africa. In B.C. Stiller, T.M. Johnson, K. Stiller, M. Hutchinson (Eds.), Evangelicals around the world: A global handbook for the 21st century (pp. 240-247). World Evangelical Alliance.

Black, E., Worth, H., Clarke, S., Obal, H.J., Akera, P., Awor, A., ... \& Richmond, R. (2109). Prevalence and correlates of intimate partner violence against women in conflict affected Uganda: A cross-sectional study. Conflict and Health, 13, 35. https://doi.org/10.1186/s13031-019-0219-8.

Blair, I.V., Steiner, J.F., \& Havranek, E.P. (2011). Unconscious (implicit) bias and health disparities: Where do we go from here? Permanente Journal, 15(2), 71-78.

Boutchie, J. (2019). Globalizing hatred. Harvard Political Review, March 15. http://harvardpolitics.com/globalizing-hatred/. Accessed 17 February 2021.

Brown, M.T., Bussell, J., Dutta, S., Davis, K., Strong, S., \& Mathew, S. (2016). Medication adherence: Truth and consequences. American Journal of the Medical Sciences, 351(4), 387-399.

Bruner, J. (2011). Keswick and the East African Revival: A historiographical reappraisal. Religion Compass, 59, 477-489.

Bruner, J. (2017). Religion, medicine and global health in Uganda: Reflecting critically on an afternoon at Mulago Hospital. Fieldwork in Religion, 12(1), 27-49.

Byabazaire, D.M. (1978). The contribution of the Christian churches to the development of Western Uganda 1894-1974. Frankfurt: Peter Lang.

Central Intelligence Agency. (2015). Uganda. In The world factbook. https://www.cia.gov/library/publications/the-world-factbook/geos/ug.html.

Chattu, V.K., \& Yaya, S. (2020). Emerging infectious disease and outbreaks: Implications for women's reproductive health and rights in resource-poor settings. Reproductive Health, 17(43). https://doi.org/10.1186/s12978-020-0899-y.

Dahir, A.L. (2017). Uganda's government is obsessed with porn and policing morality. Quartz Africa, September 6. https://qz.com/africa/1070682/uganda-has-introduced-apornography-control-committee/. Accessed 10 April 2021.

Das, P. (2005). Condom crisis in Uganda. Lancet Infectious Disease, 5(10), 601-602.

DeVries, K.M., Kishor, S., Johnson, H., Stöckl, H., Bacchus, L.J., Garcia-Moeno, C., \& Watts, C. (2010). Intimate partner violence during pregnancy: Analysis of prevalence data from 19 countries. Reproductive Health Matters, 18(36), 158-170.

Dias, E., \& Graham, R. (2021). White evangelical resistance is obstacle in vaccination effort. New York Times, April 5. https://www.nytimes.com/2021/04/05/us/covid-vaccineevangelicals.html?referringSource=articleShare. Accessed 5 April 2021.

Dodge, C.P. (1990). Health implications of war in Uganda and Sudan. Social Science \& Medicine, 31(6), 691-698.

DuBois, J. M. (2006). Vulnerability in research. In E. A. Bankert \& R. J. Amdur (Eds.), Institutional review board: Management and function (2nd ed., pp. 337-340). Sudbury, MA: Jones and Bartlett.

Fallon, A. (2014). Confusion over Uganda's 'miniskirt ban' leads to public attacks on women. The Guardian, February 28. https://www.theguardian.com/ fashion/fashionblog/2014/feb/28/uganda-miniskirt-ban-attacks-women. Accessed 10 April 2021.

Fay, H., Baral, S.D., Trapence, G., Motimedi, F., Umar, E., Iipinge, S., ... \& Beyrer, C. (2011). Stigma, health care access, and HIV knowledge among men who have sex with men in Malawi, Namibia, and Botswana. AIDS Behavior, 15(6), 1088-1097.

FitzGerald, C., \& Hurst, S. (2017). Implicit bias in healthcare professionals. BMC Medical Ethics, 18(19). doi: 10.1186/s12910-017-0179-8. 
Gubi, D., Nansubuga, E., \& Wandera, S.O. (2020). Correlates of intimate partner violence among married women in Uganda: A cross-sectional survey. BMC Public Health, 20, 1008. https://doi.org/10.1186/s12889-020-09123-4.

Gusman, A. (2009). HIV/AIDS, Pentecostal churches, and the "Joseph generation" in Uganda. Africa Today, 56(1), 66-86.

Hébert, P.C., Hoffmaster, B., Glass, K.C., \& Singer, P.A. (1997). Bioethics for clinicians: 7. Truthtelling. Canadian Medical Association Journal, 156(2), 225-228.

Hofer, K. (2003). The role of evangelical NGOs in international development: A comparative case study of Kenya and Uganda. Africa Spectrum, 38(3), 375-398.

Ihejirika, W.C. (2006). From Catholicism to Pentecostalism: The role of Nigerian televangelists in religious conversion. Port Harcourt, Nigeria: University of PortHarcourt Press.

Institute of Medicine, \& National Research Council. (2015). Preventing intimate partner violence in Uganda, Kenya, and Tanzania: Summary of a joint workshop by the Institute of Medicine, the National Research Council, and the Uganda National Academy of Sciences. Washington, DC: National Academies Press.

Isabirye, M.S. (2020). African indigenous Pentecostal Christianity in Uganda with reference to the Deliverance Church in Busoga (1974-2012). Thesis, Kenyatta University. https://ir-library.ku.ac.ke/handle/123456789/21342?show=full. Accessed 16 February 2021.

Jenga, F. (2017). Pentecostal broadcasting in Uganda. Journal of Communication \& Religion, 40(4), 53-71.

Jenkins, P. (2002). The next Christendom: The coming of global Christianity. New York: Oxford University Press.

Kagimu, M., Guwatudde, D., Rwabukwali, C., Kaye, S., Walakira, Y., \& Ainomugisha, D. (2011). Inter-religious cooperation for HIV prevention in Uganda: A study among Muslim and Christian youth in Wakiso District. Religions, 2, 707-728.

Kajungu, D., Muhoozi, M., Stark, J., Weibel, D., \& Sturkenboom, M.C.J.M. (2020). Vaccines safety and maternal knowledge for enhanced maternal immunization acceptability in rural Uganda: A qualitative study approach. PLOS One. doi.org/10.1371/journal.pone.0243834.

Kaoma, K. (2014). The paradox and tension of moral claims: Evangelical Christianity, the politicization and globalization of sexual politics in sub-Saharan Africa. Critical Research on Religion, 2(3), 227-245.

Karamagi, C., Tumwine, K., Tylleskar, T., \& Heggenhougen, K. (2006). Intimate partner violence against women in eastern Uganda: Implications for HIV prevention. BMC Public Health, 6, 284. https://doi.org/10.1186/1471-2458-6-284. Accessed 10 April 2021.

Kipnis, K. (2001). Vulnerability in research subjects: A bioethical taxonomy. In Ethical and policy issues involving human participants, vol. II. Bethesda, MD: National Bioethics Advisory Commission.

Kirby, B., Taru, J., \& Chimbidzakai, T. (2020). Pentecostals are in a "spiritual war" against coronavirus in Africa-as are some political leaders. Quartz Africa, May 1. https://qz.com/africa/1849315/pentecostal-churches-are-in-spiritual-war-vscoronavirus-covid19/. Accessed 05 April 2021.

Kisitsu, G. (2018). Religion and homosexuality criminalization in Uganda: The contribution of American anti-homosexual evangelicals towards the 2014 anti-homosexuality law. Doctoral dissertation, University of Kwazulu-Natal. https://ukzndspace.ukzn.ac.za/handle/10413/16787. Accessed 16 February 2021. 
Kouyoumdjian, F.G., Calzavara, L.M., Bondy, S.J., O’Campo, P., Serwadda, D. Nalugoda, F., ... \& Gray, R. (2013). Risk factors for intimate partner violence in women in the Rakai Community Cohort Study, Uganda, from 2000 to 2009. BMC Public Health, 13, 566.

Krieger, L.M. (2007). Stanford student under fire in Uganda for covering gay issues. Mercury News, September 3. https://www.mercurynews.com/2007/09/03/ stanford-studentunder-fire-in-uganda-for-covering-gay-issues/. Accessed 03 April 2021.

Levine, C., Faden, R., Grady, C., Hammerschmidt, D., Eckenwiler, L., \& Sugarman, J. (2004). The limitations of "vulnerability" as a protection for human research participants. American Journal of Bioethics, 4(3), 44-49.

Larsson, M., Ross, M.W., Tumwine, G., \& Agardh, A. (2016). Determinants of unmet needs for healthcare and sexual health counseling among Ugandan university students with same-sex sexuality experience. Global Health Action, 9, 30790. http://dx.doi.org/10.3402/gha.v9.30790. Accessed 18 April 2021.

Lloyd, J. (2008). Uganda's controversial pastors. Financial Times, October 24. https://www.ft.com/content/20b089e0-9f14-11dd-98bd-000077b07658. Accessed 05 April 2021.

Macrae, J., Zwi, A.B., \& Gilson, L. (1996). A triple burden for health care sector reform: "Post-conflict" rehabilitation in Uganda. Social Science \& Medicine, 42(7), 10951108.

Marcelin, J.R., Siraj, D.S., Victor, R., Kotadia, S., \& Maldonado, Y.A. (2019). The impact of unconscious bias in healthcare: How to recognize it and mitigate it. Journal of Infectious Diseases, 220 (Suppl. 2), S62-S73.

Marsden, G.M. (1980). Fundamentalism and American culture: The shaping of twentiethcentury evangelicalism. New York: Oxford University Press.

Matsiko, C.W. (2010). The Uganda country case study: Positive practice environments. International Council ofo Nurses, International Pharmaceutical Federation, World Dental Federation, World Medical Association, International Hospital Federation, World Confederation for Physical Therapy. http://www.whpa.org/sites/default/ files/2020-05/Uganda_PPE_Case_study.pdf. Accessed 18 April 2021.

McKinnon, A. (2020). Demography of Anglicans in Sub-Saharan Africa: Estimating the population of Anglicans in Kenya, Nigeria, South Africa, Tanzania and Uganda. Journal of Anglican Studies, 18(1), 42-60.

Müller, A. (2011). How and why HIV prevention efforts have undermined the rights of sexual minorities: The case of Uganda. Presented at conference on Sexuality, AIDS, and religion: Transnational dynamics in Africa, Oxford University, September 29.

Murphy, E.M., Greene, Mihailovic, A., \& Olupot-Olupot, P. (2006). Was the "ABC" approach (abstinence, being faithful, using condoms) responsible for Uganda's decline in HIV? PLoS Medicine, 3(9). doi: 10.1371/journal.pmed.0030379.

Musana, P. (1991). The historical origins and development of Pentecostal movement in Uganda. Unpublished MA manuscript, Department of Religious Studies, Makerere University, Kampala, Uganda.

Namige, R.N. (2019). Towards the management of HIV/AIDS patients in Pentecostal churches in Uganda: a case of Eden and Bethel Churches in Kampala [P275]. Sexually Transmitted Infections, 95, A158-A159.

Namutebi, J., \& Kashaa, U. (2014). Cabinet to review anti-pornography law. New Vision, February 26, at 5.

Ndyabahika, J. (1993). The revival movement in Uganda: An evaluation. Africa Journal of Evangelical Theology, 12(1), 18-40. 
Niang, C.I., Tapsoba,, P., Weiss, E., Diagne, M., Niang, Y., Moreau, A.M., ... \& Castle, C. (2003). 'It's raining stones': Stigma, violence and HIV vulnerability among men who have sex with men in Dakar, Senegal. Culture, Health, and Sexuality, 5(6), 499-5 12.

Ogland, E.G., Xu, X., Bartkowski, J.P., \& Ogland, C.P. (2014). Intimate partner violence against married women in Uganda. Journal of Family Violence, 29, 869-879.

Oliver, M. (2013). Transnational sex politics, conservative Christianity, and antigay activism in Uganda. Studies in Social Justice, 1, 83-105.

Oloka-Onyango, J. (2014). Understanding the genesis and impact of recent legislation in Uganda. Pambazuka News, May 1. https://www.pambazuka.org/governance/ understanding-genesis-and-impact-recent-legislation-uganda. Accessed 10 April 2021.

Oloka-Onyango and Ors v. Attorney General, Constitutional Petition No. 8 of 2014 (Uganda Constitutional Court, August 1, 2014).

Onyait, S.R. (2011). The Christian faith and development work: An assessment of the historical and contemporary trends in the Pentecostal Assemblies of God in Kumi District-Eastern Uganda. https://www.academia.edu/39122736/The_Christian _Faith_and_Development_Work20190514_130338_y9tmhf. Accessed 16 February 2021.

Parikh, S. (2015). Regulating romance: Youth love letters, moral anxiety, and intervention in Uganda's time of AIDS. Nashville, TN: Vanderbilt University Press.

Parliament of Uganda, AntiHomosexuality Bill, 2009, No. 18, Principle 1.1.

Penal Code Act. (1956).

Penal Code of Uganda, Chapter 120, as amended (2014). https://ulii.org/ akn/ug/act/ord/1950/12/eng\%402014-05-09. Accessed 14 April 2021.

Perkins, A. (2008). Religion and sex in Uganda: The power of the pulpit. The Guardian, October

https://www.theguardian.com/society/katineblog/2008/oct/13/sexandreligion.

Accessed 13 June 2021.

Pownall, K.P. (2007). Ugandans call for deportation of American journalist covering gay issues. The Advocate, August 22. https://www.advocate.com/news/2007/08/ 22/ugandans-call-deportation-american-journalist-covering-gay-issue. Accessed 03 April 2021.

Reeve, E., Guff, S., Waldrop, T., \& Brunswick, D. (2021). Many evangelicals say they won't be vaccinated against covid-19. Some experts say distrust and misinformation have played a role. CNN, April 15. https://www.cnn.com/2021/04/14/us/covid-vaccineevangelicals/index.html. Accessed 24 April 2021.

Rispel, L.C., Metcalf, C.A., Cloete, A., Moorman, J., \& Reddy, V. (2011). You become afraid to tell them that you are gay: Health service utilization by men who have sex with men in South African cities. Journal of Public Health Policy, 32(Suppl. 1), S137-S51.

Rogers, W., Mackenzie, C., \& Dodds, S. (2012). Why bioethics needs a concept of vulnerability. International Journal of Feminist Approaches to Bioethics, 5(2), 11-38.

Roubos, K. (2016). Declaration of Katherine Roubos, Sexual Minorities v. Lively (D.C. Mass. No. 3:12-CV-30051-MAP), July 31, 2016 (Document 287, filed August 8, 2016). $\quad$ http://files.eqcf.org/wp-content/uploads/2016/11/287-Declaration-ofRoubos.pdf. Accessed 03 April 2021.

Rowe, K., \& Moodley, K. (2013). Patients as consumers of health care in South Africa: The ethical and legal implications. BMC Medical Ethics, 14(15). Doi.org/10.1186/14726939-14-15. 
Sadgrove, J. (2007). 'Keeping up appearances': Sex and religion amongst university students in Uganda. Journal of Religion in Africa, 37(1), 116-144.

Salvo, S. (2014). Women challenge "mini-skirt ban" in Uganda's intensifying crackdown. Human Rights First, March 5. https://www.humanrightsfirst.org/ blog/womenchallenge-\%E2\%80\%9Cmini-skirt-ban\%E2\%80\%9D-uganda\%E2 \%80\%99sintensifying-crackdown. Accessed 10 April 2021.

Sekyewa, E.R. (2014). Anti-porn law to be reviewed after attacks on women. Index on Censorship, March 10. https://www.indexoncensorship.org/2014/03/porn-billuganda/. Accessed 10 April 2021.

Semakula, J. (2019). Ugandan government closes nearly 12,000 churches and faith-based NGOs. Religion Unplugged, November 25. https://religionunplugged.com/news/ 109/11/25/ugandan-government-closes-1200-churches-faith-based-ngos. Accessed 17 February 2021.

Setswe, G. (2007). Abstinence and faithfulness programs for prevention of HIV/AIDS among young people: What are the current debates? South Africa Family Practice, 49(8), 510.

Sharma, A., Bukusi, E., Gorbach, P., Cohen, C.R. Muga, C., Kwena, Z. \& Holmes, K.K. (2008). Sexual identity and risk of HIV/STI among men who have sex with men in Nairobi. Sexually Transmitted Disease, 35(4), 352-354.

Smith, R. (2015). Healthcare experiences of lesbian and bisexual women in Cape Town, South Africa. Culture, Health and Sexuality, 17, 180-193.

Ssejoba, E. (2004). Museveni condemns condom distribution to pupils. New Vision, May 17.

Ssemugoma, F. (2021). The march of Christianity in Uganda: History of Christianity in Uganda. Monee, IL: Author.

Tamale, S. (2016). Crossing the bright red line: The abuse of religion to violate sexual and reproductive health rights in Uganda. Journal of Theology for Southern Africa, 155, 121-136.

Tomaselli, K.G. (1995). Political economy of televangelism: Ecumenical broadcasting versus teleministries. Communicare, 14, 65-79.

Tomaselli, K.G., \& Shepperson, A. (1997). Resistance through mediated orality. In S.M. Hoover, K. Lundby (Eds.), Rethinking media, religion and culture (pp. 209-224). Thousand Oaks, CA: Sage Publications.

Tumwine, C., Neema, S., \& Wagner, G. (2012). Reasons why high religiosity can co-exist with and precipitate discontinuation of antiretroviral therapy among different HIV clients in Uganda: An exploratory study. Religions, 3, 817-832.

Uganda AIDS Commission. (2015). National HIV and AIDS strategic plan 2015/20162019/2020: An AIDS free Uganda, my responsibility! Uganda: Author. http://cquin.icap.columbia.edu/wp-content/uploads/2017/06/ICAP_CQUIN_NationalHIV-and-AIDS-Strategic-Plan_2015-16-2019-20.pdf. Accessed 13 June 2021.

Uganda Bureau of Statistics (UBOS). (2014). National population and housing census: main report. Kampala: Uganda Bureau of Statistics.

Uganda Bureau of Statistics (UBOS), \& ICF. (2018). Uganda demographics and health survey, 2016. Kampala, Uganda and Rockville, MD: Authors. https://dhsprogram.com/pubs/pdf/FR333/FR333.pdf. Accessed 10 April 2021.

Uganda Bureau of Statistics (UBOS). (2002). 2002 Uganda population and housing census: Analytical report. Kampala: Uganda Bureau of Statistics.

Uganda Law Reform Commission. (2017). Medical negligence in Uganda: Issues paper. https://www.ulrc.go.ug. Accessed 18 April 2021. 
Uganda Medical and Dental Practitioners Council. (2013). Code of ethics. https://www.umdpc.com/Resources/Code\%20of\%20Professional\%20Ethics.pdf. Accessed 18 April 2021.

United States Department of State. (2019). Uganda 2019 international religious freedom report. https://www.state.gov/wp-content/uploads/2020/05/UGANDA-2019INTERNATIONAL-RELIGIOUS-FREEDOM-REPORT.pdf. Accessed 10 March 2021.

Valentine, A., Akobirshoev, I., \& Mitra, M. (2019). Intimate partner violence among women with disabilities in Uganda. International Journal of Environmental Research and Public Health, 16, 947. doi: 10.3390/ijerph16060947.

van der Laan, F., \& van der Wal, E. (2014). Anti-queer morality in Uganda. Capstone project, Universiteit Utrecht. https://uu.academia.edu/FleurvanderLaan. Accessed 14 April 2021.

van Klinken, A., \& Zebracki, M. (2016). Porn in church: Moral geographies of homosexuality in Uganda. Porn Studies, 3(1), 89-92.

Wakabi, W. (2008). New strategies sought in Uganda as HIV infections rise. Lancet Infectious Disease, 8(5), 285.

Waliggo, J.M. (2004). The church and HIV/AIDS (A Ugandan pastoral experience). African Ecclesial Review, 46(1), 23-34.

Wandera, D. (2014). Anti-pornography law was misunderstood, says Minister. Daily Monitor, March 5.

Wanyama, J., Castenuovo, B., Wandera, B., Mwebaze, P., Kambiugu, A., Bangsberg, D.R., \& Kamya, M.R. (2007). Belief in divine healing can be a barrier to antiretroviral therapy adherence in Uganda. AIDS, 21, 1486-1487.

Ward, K. (2001). 'The Armies of the Lord': Christianity, rebels and the state in Northern Uganda, 1986-1999. Journal of Religion in Africa, 31(2), 187-221.

Ward, K. (1989). "Obedient rebels": The relationship between the early "Baokole" and the Church of Uganda: The Mukono crisis of 1941. Journal of Religion in Africa, 19(3), 194-227.

Ward, K. (2015). The role of the Anglican and Catholic churches in Uganda in public discourse on homosexuality and ethics. Journal of Eastern African Studies, 9(1), 127 144.

Waweru, E., Sarkar, N.D.P., Ssengoba, F., Gruénais, Broerse, J., \& Criel, B. (2019). Stakeholder perceptions on patient-centered care at primary health care level in rural eastern Uganda: A qualitative inquiry. PLoS ONE, 14(8), e0221649. https://doi.org/10.1371/journal.pone.0221649.

Wiener-Bronner, D. (2014). Ugandan tabloid publishes list of 'top 200' homosexuals who could now be jailed. The Atlantic, February 25. https://www.theatlantic. com/international/archive/2014/02/ugandan-tabloid-publishes-list-top-200homosexuals-who-could-now-be-jailed/358478/. Accessed 03 April 2021.

Wolffe, J. (2015). Who are evangelicals? A history. In B.C. Stiller, T.M. Johnson, K. Stiller, M. Hutchinson (Eds.), Evangelicals around the world: A global handbook for the 21st century (pp. 25-33). World Evangelical Alliance.

Yolisigira, Y. (2014). Mob undresses 10 people over indecent exposure. Daily Monitor, February 26. https://ugandansatheart.blogspot.com/2014/03/uah-jiggers-syndromemob-undresses-10.html. Accessed 10 April 2021.

Young, C.R., Kaida, A., Kabakyenga, J., Muyindike, W., Musinguzi,, N., Martin, J.N., ..., \& Matthews, L.T. (2018). Prevalence and correlates of physical and sexual intimate partner violence among women living with HIV in Uganda. PLoS One, 13(8), e0202992. https://doi.org/10.1371/journal.pone.0202992. 
Zurlo, G.A. (2015). Demographics of global evangelicalism. In B.C. Stiller, T.M. Johnson, K. Stiller, M. Hutchinson (Eds.), Evangelicals around the world: A global handbook for the 21 st century (pp. 34-47). World Evangelical Alliance. 